\title{
Effect of Some Growing Media on Growth and Flowering of Gazania Plant
}

\author{
Badreya A.Hassan ${ }^{1}$, Mahmoud K.Hussein ${ }^{2}$,Tarek M.El-Kiey ${ }^{2}$ and Bothaina M.Weheda ${ }^{1}$
}

\begin{abstract}
The present investigation was carried out at the Horticulture Research Institute, Agricultural Research Center, Ministry of Agriculture, Alexandria Egypt during the year of 2012 at two different locations i.e. Maamoura and Montaza.
\end{abstract}

The aim of this study was to evaluate the effects of using 6 different media which produced from adding different ratios $(v / v)$ of compost or/ and sand to the calcareous soil on the vegetative growth, flowering characteristics and some chemical analysis of Gazania rigens $L$. grown in $25 \mathrm{~cm}$ diameter clay pots.

Generally results of the two locations revealed that using calcareous soil alone gave the lowest values of most of the studied parameters of Gazania plant, compared with other media.

While adding compost at $25 \%$ or $50 \%$ to the calcareous soil led to significant increases of almost all the measured parameters of Gazania plant, compared with using calcareous soil alone.

Furthermore, adding sand at $25 \%$ or $50 \%$ to the calcareous soil or using an equal mixture of calcareous soil at $33.3 \%$, compost at $33.3 \%$ and sand at $33.3 \%$ did not gave any significant effect on most of the studied parameters of Gazania plant, compared with using calcareous soil alone with exceptions of inflorescence diameter, pedicle length, inflorescence dry weight and leaf content of $\mathrm{N}, \mathrm{P}, \mathrm{K}, \mathrm{Mn}$ and $\mathrm{Zn}$.

It can be generally recommended to add compost at $25 \%$ to the calcareous soil to obtain a good growing medium for growing Gazania rigens with high quality.

\section{INTRODUCTION}

Gazania rigens L. (Syn.G.splendens), sometimes called treasure inflorescences, is a species of flowering plant in family Asteraceae, native to Southern Africa. It is naturalized elsewhere and is widely cultivated as an ornamental garden plant. It is spreading low -growing, half-hardly perennial, growing to $50 \mathrm{~cm}$ tall and wide, with blue-grey foliage and brilliant yellow, daisy-like composite inflorescences heads. Gazania produced inflorescences all-round the year, especially in summer season. They close at night and during cloudy weather, so they are not usable as cut inflorescences.

The plants prefer a sunny position and are tolerant of dryness and poor soils. Plants are tolerant to salt and can be used in coastal regions very effectively (Ball,

\footnotetext{
${ }^{1}$ Montaza Research Branch, Horticultural Research Institute,

A.R.C, Alexandria, Egypt.

${ }^{2}$ Dept.of Floriculture, Ornamental Horticultural and

Landscape Gardening, Faculty of Agriculture, Alexandria University.

Received January 5, 2015, Accepted March 2, 2015
}

1992). The plants are used in the garden in different positions i.e. in beds, borders, pots, wall gardens.....etc. and they can also be mixed with other plants.

A calcareous soil is the soil which containing more than $10 \% \mathrm{CaCO}_{3}$. It was defected with the loss of the water irrigation quickly. $\mathrm{CaCO}_{3}$ was assembled in a layer and become not executer, and it was hindered the airing and the water motion in the soil and the high value of $\mathrm{pH}$ affected the suitability of some elements such as $\mathrm{P}, \mathrm{Fe}, \mathrm{Mn}$ and $\mathrm{Zn}$.

This kind of soil spread in the northern western coast from Alexandria to the west limits of Egypt and in lot of the Arab countries, especially located in Mediterranean basin.

Soil physical condition is one factor that can limit crop production. Poor soil physical condition can restrict water intake into soil and subsequent movement, plant root development and aeration of the soil. Producers and researchers are interested in improving the physical soil condition and thus enhance crop production. These goals can be accomplished in part through the use of good management techniques. In addition, there are amending materials that claim to improve the soil physical conditions, such materials are called soil conditioners.

Soil conditioners vary greatly in their composition, application rate, and mode of action. Several natural materials have been found to improve various physical properties of the calcareous soil such as compost, sand and others. Abou-Bakr and El-Maghraby (1994) in a study on sugar beet var. Sofi, they showed that compost application increased soil organic carbon, organic matter and total $\mathrm{N}$. They added that vegetative growth and root weight were increased by using compost at $2 \%$, with no further significant increase from the higher application rate.

El-Gizy and Rifaat (2001) indicated that, application of saw dust compost to calcareous soil in Giza , significantly increased number of leaves, fruit yield and nutrient uptake of both line 73 and Florada tomato cultivars.

Abd El-Kader et al. (2010) applied plant residues compost and chicken manure at the rate of $6 \mathrm{~m}^{3} /$ acre to okra plants and found that organic compost increased 
plant height, stem diameter and fresh weight, number of branches and leaves, and leaf area/plant.

The present study was carried out to investigate the effects of adding different ratios of two natural soil conditioners, i.e., compost and sand to the calcareous soil on the vegetative growth flowering and some chemical analysis of Gazania plant under the prevailing condition in Alexandria region.

\section{MATERIALS AND METHODS}

The present study was carried out during March till November of 2012 at two different locations of Alexandria city i.e., Maamoura and Montaza Research Branch, Horticulture Research Institute, Ministry of Agriculture.

Averages of temperature degree and relative humidity of Maamoura were $34.2^{\mathrm{O}} \mathrm{c}$ and $63 \%$ while for Montaza were $30.0^{\circ} \mathrm{c}$ and $62 \%$, respectively during the growing season of Gazania plant. Similar terminal stem cuttings were taken from the mother plants grown in Montaza location on March 2012, with an average length of $10 \mathrm{~cm}$ and contained 5 leaves for each one. These cuttings were planted directly in $25 \mathrm{~cm}$ clay pots filled with different growing media at one cutting per pot. The planted cuttings were placed in a partial shade place for three weeks and watered as needed. After that the plants were arranged in the experiment and left for another 24 days with removing all the formed inflorescence buds to encourage the vegetative growth only, and then the plants were left for other 7 months for flowering.

Calcareous soil was brought from the northern western coast $37.5 \mathrm{~km}$ far off Alexandria city, then it was mixed with different ratios $(\mathrm{v} / \mathrm{v})$ of two natural soil condioners, i.e., compost (rich) and sand (yellow).

Six growing media were used namely, 1- 100\% calcareous soil, $2-75 \%$ calcareous soil $+25 \%$ compost, 3- $50 \%$ calcareous soil $50 \%$ compost, $4-75 \%$ calcareous soil $+25 \%$ sand, $5-50 \%$ calcareous soil $+50 \%$ sand. $6-33.3 \%$ calcareous $+33.3 \%$ compost + $33.3 \%$ sand. The analysis of the used growing media is presented in Table (A).

The plants were fertilized with a complete fertilizer of $19 \mathrm{~N}: 19 \mathrm{P}_{2} \mathrm{O}_{5}: 19 \mathrm{~K}_{2} \mathrm{O}$ at a rate of one gram per liter of irrigation water. Fertilizer was applied twice weekly during May, October and November, and three times during June, July, August and September.

A layer of plastic sheet was placed on the soil surface under the clay pots to prevent the plant roots to insert into the soil.

The experimental design was a randomized complete blocks design with 6 treatments in four replicates and four plants were used for each treatment (plot). The means of individual factors were compared by L.S.D. test at 5\% level of probability (Snedecor and Cochran, 1974).

The following data were recorded: plant diameter, number of tillers/ plant, leaves number/ plant, leaf area/ plant, leaves dry weight/ plant, plant dry weight inflorescences diameter, pedicle length, total number of inflorescences /plant, inflorescences duration on plant, inflorescence dry weight, root volume, root dry weight ,total chlorophyll content (Yadava, 1986), and leaf content at nitrogen (Evenhuis and Dewaard, 1980) phosphorus, potassium, copper, iron, manganese and zinc (Chapman and Pratt, 1961).

Table A. Analysis of the used media.

\begin{tabular}{|c|c|c|c|c|c|c|c|c|c|c|c|c|}
\hline \multirow[t]{2}{*}{$\begin{array}{l}\text { Medium } \\
\text { number }\end{array}$} & \multirow[t]{2}{*}{ Texture } & \multirow[t]{2}{*}{ pH } & \multirow[t]{2}{*}{$\begin{array}{c}\text { EC } \\
\text { dsm-1 }\end{array}$} & \multicolumn{3}{|c|}{$\begin{array}{l}\text { Macro nutrients } \\
\mathrm{mg} / \mathrm{kg}\end{array}$} & \multicolumn{4}{|c|}{$\begin{array}{l}\text { Micro nutrients } \\
\quad(\mathbf{p p m})\end{array}$} & \multirow{2}{*}{$\begin{array}{c}\mathrm{CaCO} \\
3 \\
(\%)\end{array}$} & \multirow{2}{*}{$\begin{array}{c}\text { Field } \\
\text { capacity } \\
(\%)\end{array}$} \\
\hline & & & & $\mathbf{N}$ & $\mathbf{P}$ & $\mathbf{K}$ & $\mathrm{Zn}$ & $\mathbf{F e}$ & $\mathbf{F e}$ & $\mathbf{Z n}$ & & \\
\hline 1 & $\begin{array}{l}\text { Sandy } \\
\text { Loam }\end{array}$ & 7.99 & 8.51 & 161 & 10.4 & 100 & 3.42 & 2.76 & 2.76 & 3.42 & 85.40 & 15.77 \\
\hline 2 & $\begin{array}{l}\text { Loamy } \\
\text { Sand }\end{array}$ & 7.80 & 20.20 & 168 & 55.0 & 2400 & 3.75 & 5.39 & 5.39 & 3.75 & 73.90 & 26.65 \\
\hline 3 & $\begin{array}{l}\text { Loamy } \\
\text { Sand }\end{array}$ & 7.70 & 38.40 & 196 & 322.0 & 5800 & 7.11 & 8.64 & 8.64 & 7.11 & 38.30 & 43.42 \\
\hline 4 & $\begin{array}{l}\text { Sandy } \\
\text { Loam }\end{array}$ & 7.84 & 7.37 & 133 & 3.2 & 60 & 3.08 & 1.44 & 1.44 & 3.08 & 74.50 & 16.92 \\
\hline 5 & $\begin{array}{l}\text { Sandy } \\
\text { Loam }\end{array}$ & 7.78 & 5.66 & 140 & 6.2 & 80 & 3.11 & 0.72 & 0.72 & 3.11 & 51.50 & 16.85 \\
\hline 6 & $\begin{array}{l}\text { Sandy } \\
\text { Loam }\end{array}$ & 7.57 & 24.50 & 182 & 82.0 & 3400 & 4.68 & 5.75 & 5.75 & 4.68 & 63.40 & 30.14 \\
\hline
\end{tabular}




\section{RESULTS AND DISCUSSION}

Vegetative growth characteristics:

Generally, data of the present study in the two locations showed that using calcareous soil alone gave the lowest values of all vegetative growth parameters of Gazania plant, compared with the other media, with one exception of leaf number in one location (Maamoura) (Tables 1 and 2).

These results may be attributed to the properties of the calcareous soils which have a high $\mathrm{pH}$ value (7.99) due to their high content at calcium carbonate $(>85 \%)$, low cation exchange capacity, low water content $(15.77 \%)$ and low fertility at most of macro- and micro elements. Thus, less water is available to plants. Nutrient uptake is also decreased as water availability decreases. Therefore, drought and nutrient stress can occur simultaneously. All these factors led to inhibit the vegetative growth of the used plant. These results were agreed with those obtained by El-Sayed (1991) and Singh (1999) on other plants.

Besides, adding compost at a rate of $25 \%$ or $50 \%$ to the calcareous soil led to significant increases of most of the vegetative growth parameters (number of tillers per plant, leaf number, leaf dry weight, leaf area and plant dry weight), compared with using calcareous soil alone (Tables 1 and 2).

These results were probably due to the presence of compost at a specific ratio which benefit the calcareous soil principally by improving soil structure, water penetration, moisture holding capacity, supply moderate nutrient and hums. Consequently all the vegetative growth parameters of Gazania could be increased, compared with the growing plant in the calcareous soil alone. These results are like that obtained by El-Mahdy (2001), Wang et al. (2003), El-Sayed and El-Shal (2008), Abd El-Kader et al. (2010), Mazher et al. (2012) and Fadl (2013) on other plants.

Furthermore, results of the two locations showed that adding sand at $25 \%$ or $50 \%$ to the calcareous soil did not show any significant effect on almost all vegetative growth parameters of the used plant, compared with using calcareous soil alone, with one exception of leaf-area in one location (Montaza).

These results were probably due to that mixing sand at $25 \%$ or $50 \%$ with calcareous soil could not be improved the physical or the chemical properties of the calcareous soil, because sand is a poor medium in its nutrient elements content, and it does not keep enough water. Similar result was reported by El-Sayed and ElShal (2008) on other plants.

Also, results of the two locations illustrated that adding compost at $33.3 \%$ and sand at $33.3 \%$ to $33.3 \%$ calcareous soil did not gave any significant effect on most of the vegetative growth parameters of Gazania plant, compared with using calcareous soil alone, with exceptions of leaf area and number of tillers and leaf number in one location for each (Tables 1 and 2).

These results may be due to that the presence of sand at a specific ratio in the calcareous soil led to decrease the moisture holding capacity of the calcareous soil, consequently the benefit of the cultivated plant from the adding compost could be decreased. These results were agreed with those obtained by Abo El-Fadl et al. (1989), El-Sayed (1991) and El- Mahdy (2001) on other plants.

\section{Flower characteristics:}

Generally, using calcareous soil alone gave the minimum values of most of the flower parameters (total number of inflorescences per plant, inflorescences diameter and inflorescences duration compared with the other media in the two locations (Table 3).

These results were probably due to that calcareous soil had unsuitable properties for growing Gazania plants such as high in $\mathrm{pH}$ value and calcium carbonate, low fertility, low water content, low cation exchange capacity...etc., consequently producing weak plants with low flower quality. Similar results were obtained by El-Sayed (1991) on Chrysanthemum and Dianthus.

Besides, data of the two locations in (Table 3) indicated that adding compost at $25 \%$ or $50 \%$ to the calcareous soil led to significant increases of all flower parameters of Gazania plant, compared with using calcareous soil alone.

These results may be related to the presence of compost at a suitable ratio which led to improve the soil characters and provide the plants with minerals, consequently the vegetative growth parameters of the used plant would be increased, thus their flower quality would be improved. Similar trend of results was reported by Sayed (1993), Manoly (1996), El-Menaie et al. (2008) and Mazher et al. (2012) on other plants.

Furthermore data in Table (3) showed that adding sand at $25 \%$ or $50 \%$ to the calcareous soil did not gave any significant effect on most of the flower parameters of the used plant, compared with using calcareous soil alone, with one exception of inflorescence diameter.

These results were probably due to the presence of sand which led to increase the loosing amount of soil water thus the plant could not be absorbed the adequate amount of water and nutrition for the good growth with a high flower quality. Similar result was obtained by ElSayed (1991) on Chrysanthemum and Dianthus. 

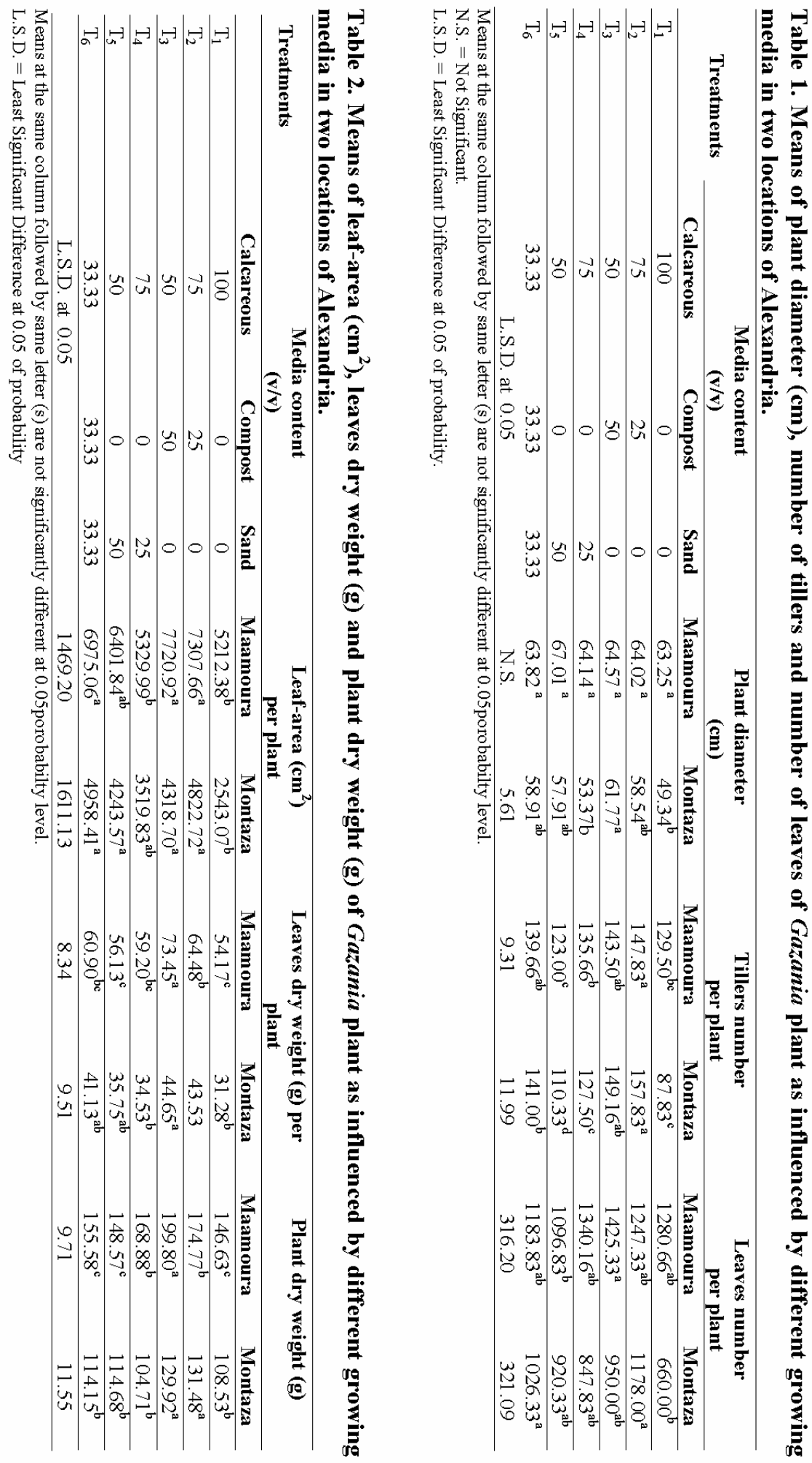


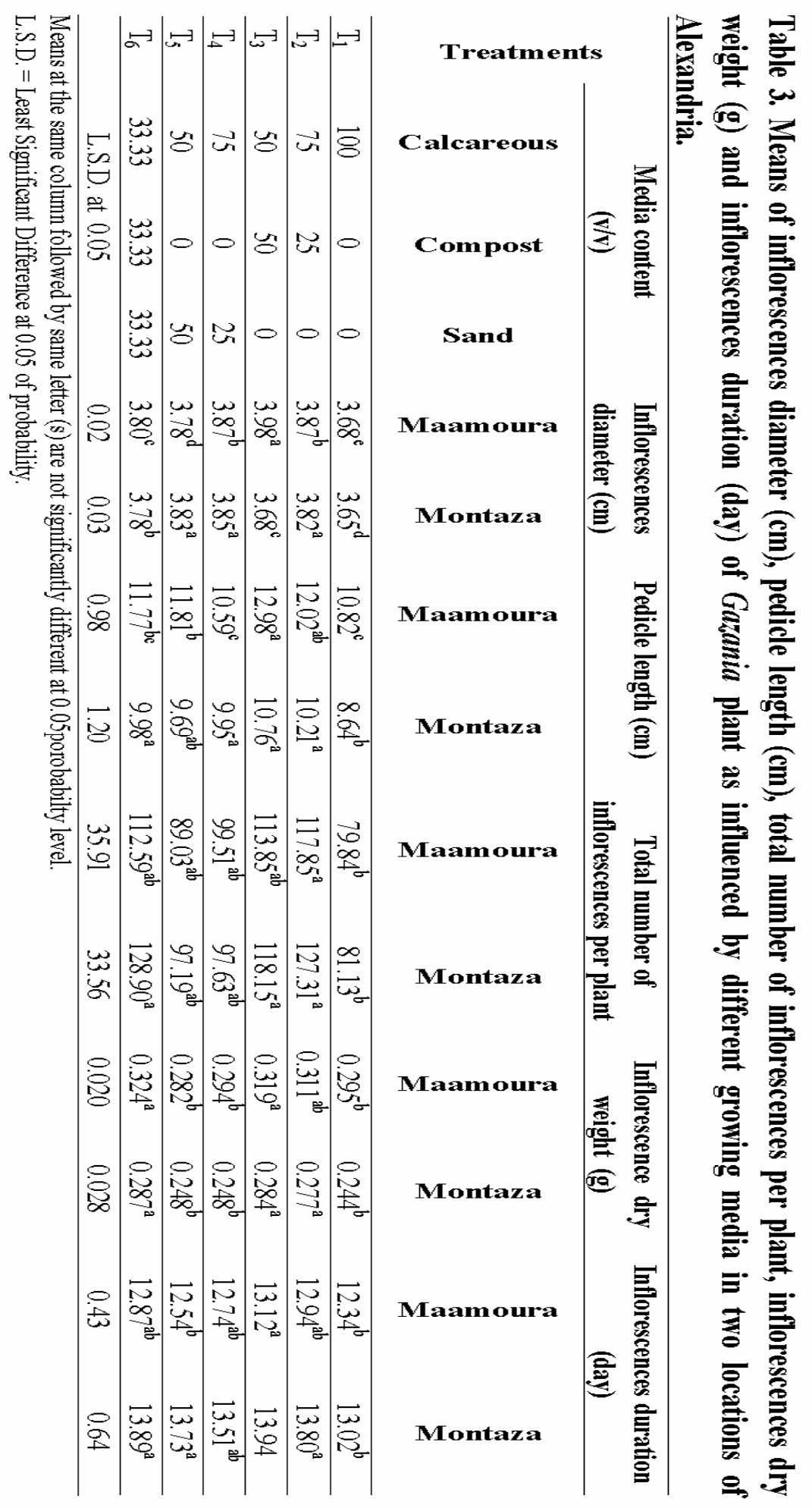


Generally, data of the two locations in Table (3) indicated that using an equal mixture of the three materials (calcareous soil, compost and sand) led to significant increases in some flower parameters such as pedicle length, number of inflorescences /plant and inflorescences dry weight, compared with growing Gazania in calcareous soil alone. These results may be probably mainly due to the presence of compost which led to improve some calcareous soil properties such as decreasing each of calcium carbonate content and $\mathrm{pH}$ value and increasing the nutrient content and percentage of field capacity (Table A), which led to improve some vegetative growth parameters such as leaf area, consequently some flower parameters could be increased, compared with using calcareous soil alone.

\section{Roots growth characteristics:}

Generally, the results of the two locations indicated that using the third growing media which had the highest compost ratio $(50 \%)$ gave the maximum significant values of the root volume and dry weight of Gazania plant, compared with the calcareous soil alone (Table 4).

These results may be attributed to the importance of adding compost at specific ratio to the calcareous soil, which led to improve the soil texture and some of physical and chemical properties of it, consequently the root growth parameters could be increased. Similar trend of results was obtained by Zhao (2002), Mazher et al. (2012) and Fadl (2013) on other plants.

Besides, results of the two locations indicated that adding sand to the calcareous soil at any ratio did not significantly affect the root volume or dry weight of the used plant, compared with using calcareous soil alone.

These results were probably due to that adding sand at any ratio to the calcareous soil did not improve the soil texture and the physical or the chemical properties of it, consequently the root growth parameters could not be significantly increased. Similar trend of results was obtained by Zhao (2002), Mazher et al. (2012) and Fadl (2013) on other plants.

\section{Chemical analysis}

\section{Chlorophyll contents}

Generally, using calcareous soil alone led to decrease the values of the chlorophyll content in the leaves of Gazania plant, compared with the other media (Table 5).

These results were probably due to the high $\mathrm{pH}$ value (7.99) of the calcareous soil compared with the other growing media, which led to decrease the availability and the absorbed amount of the important elements for chlorophyll formation in the plants such as nitrogen, magnesium and others leading to decrease in the biosynthesis of chlorophyll in Gazania leaves. Similar results were obtained by Badr et al. (1979) on other ornamental plants.

Besides, data of the two locations indicated that adding compost at $25 \%$ or $50 \%$ to the calcareous soil gave the highest significant values of chlorophyll content in the leaves of the used plant, compared with using calcareous soil alone (Table 5).

These results may be attributed to the increase in the solubility and availability of some elements affecting chlorophyll formation such as nitrogen, magnesium and other elements resulted from adding compost at a suitable ratio which led to decrease the values of soil $\mathrm{pH}$ from 7.99 to 7.80 and 7.70 , respectively (Table A) and soil carbonate content from $85.40 \%$ to $73.9 \%$ and $38.31 \%$, respectively consequently the biosynthesis of chlorophyll in the leaves could be increased. These results are in good agreement with those obtained by ElNaggar et al. (2004), Abd EL-Hady (2006), AbdelFattah et al. (2008), Yang et al. (2010) and Agamy et al. (2012) on other plants.

Table 4. Means of root volume $(\mathrm{cm} 3)$ and root dry weight $(\mathrm{g})$ of Gazania plant as influenced by different growing media in two locations of Alexandria.

\begin{tabular}{cccccccc}
\hline \multirow{2}{*}{ Treatments } & \multicolumn{2}{c}{$\begin{array}{c}\text { Media content } \\
\text { (v/v) }\end{array}$} & \multicolumn{3}{c}{$\begin{array}{c}\text { Root volume (cm3) per } \\
\text { plant }\end{array}$} & \multicolumn{2}{c}{$\begin{array}{c}\text { Root dry weight (g) per } \\
\text { plant }\end{array}$} \\
\cline { 2 - 8 } & Calcareous & Compost & Sand & Maamoura & Montaza & Maamoura & Montaza \\
\hline $\mathrm{T}_{1}$ & 100 & 0 & 0 & $237.50^{\mathrm{c}}$ & $191.66^{\mathrm{b}}$ & $54.21^{\mathrm{c}}$ & $48.76^{\mathrm{b}}$ \\
\hline $\mathrm{T}_{2}$ & 75 & 25 & 0 & $289.16^{\mathrm{bc}}$ & $285.83^{\mathrm{a}}$ & $89.36^{\mathrm{bc}}$ & $51.45^{\mathrm{b}}$ \\
\hline $\mathrm{T}_{3}$ & 50 & 50 & 0 & $476.66^{\mathrm{a}}$ & $273.33^{\mathrm{a}}$ & $142.15^{\mathrm{a}}$ & $75.18^{\mathrm{a}}$ \\
\hline $\mathrm{T}_{4}$ & 75 & 0 & 25 & $293.33^{\mathrm{bc}}$ & $220.00^{\mathrm{ab}}$ & $84.08^{\mathrm{bc}}$ & $68.31^{\mathrm{ab}}$ \\
\hline $\mathrm{T}_{5}$ & 50 & 0 & 50 & $326.66^{\mathrm{b}}$ & $262.50^{\mathrm{ab}}$ & $63.18^{\mathrm{c}}$ & $39.85^{\mathrm{b}}$ \\
\hline $\mathrm{T}_{6}$ & 33.33 & 33.33 & 33.33 & $315.83^{\mathrm{b}}$ & $219.16^{\mathrm{ab}}$ & $83.16^{\mathrm{bc}}$ & $56.26^{\mathrm{ab}}$ \\
\hline L.S.D. at 0.05 & & & & 72.81 & 75.07 & 24.26 & 22.76 \\
\hline
\end{tabular}

Means at the same column followed by same letter (s) are not significantly different at 0.05 porobabilty level.

L.S.D. = Least Significant Difference at 0.05 of probability. 


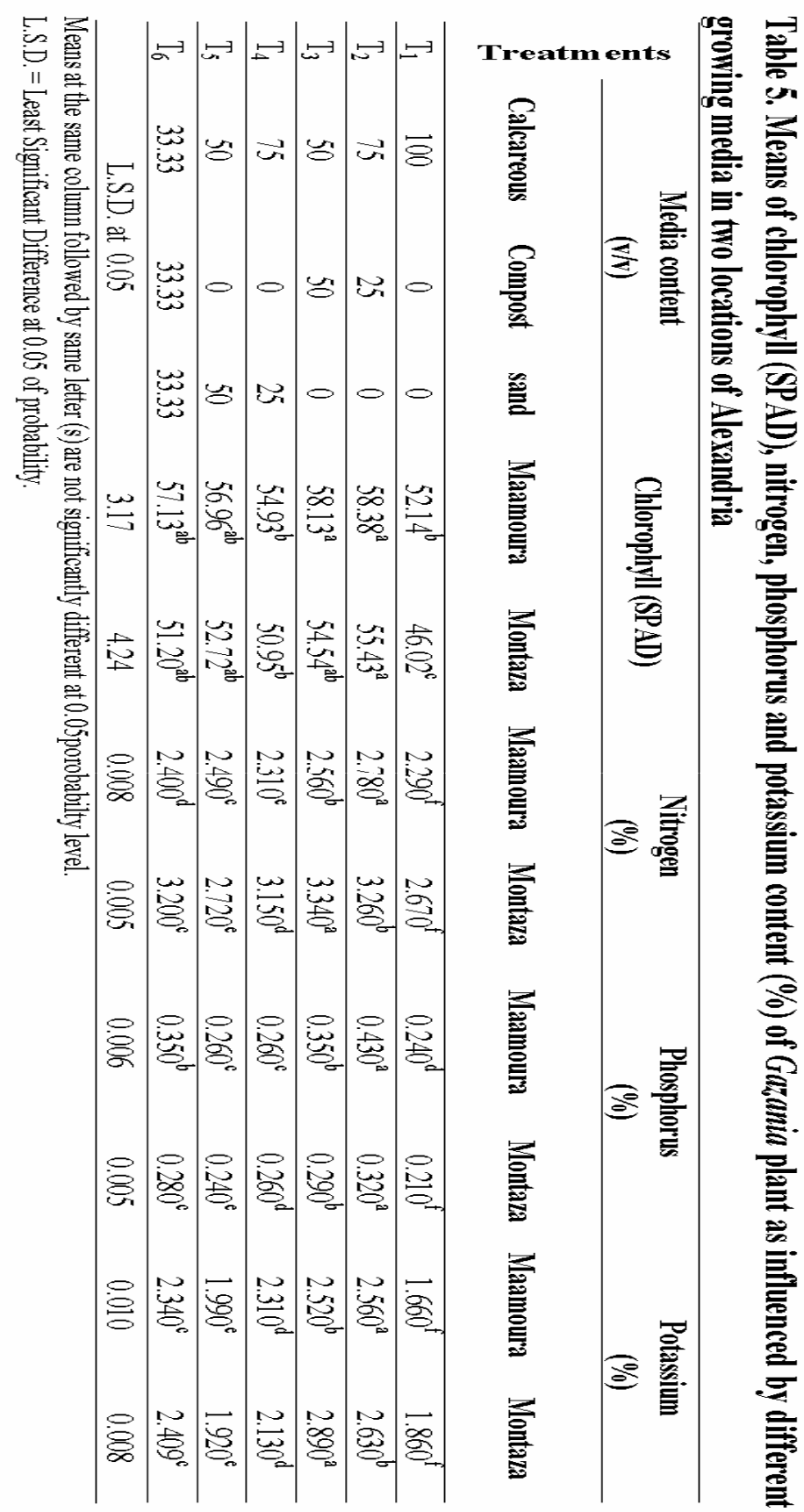


Furthermore, data of the two locations showed that adding sand at $25 \%$ or $50 \%$ to the calcareous soil or using an equal mixture from calcareous soil, compost and sand had no significant effect on the values of chlorophyll content in the leaves of the used plant, compared with using calcareous soil lone, with one exception of Montaza location which was significant (Table 5).

These results were probably due to that increasing the ratio of sand in calcareous soil led to increase in the amount of soil water loosing by drainage, as a result the absorbed amount of the essential elements for chlorophyll formation would be decreased, consequently the chlorophyll value in the plant leaf would be decreased. Similar trend of results was obtained by Badr et al. (1979) on other ornamental plants.

\section{Mineral elements content:}

Generally, data of the two locations indicated that using calcareous soil alone led to decrease the content of $\mathrm{N}, \mathrm{P}, \mathrm{K}, \mathrm{Cu}, \mathrm{Mn}$ and $\mathrm{Zn}$ in the leaves of Gazania plant, compared with the other media (Tables 5 and 6).

These results were probably due to the unsuitability properties of the calcareous soil for growing plants as a result of its high $\mathrm{pH}$, high calcium carbonate, low cation exchanges capacity, ... etc, consequently the availability of most of the nutrition elements would be decreased, thus the grown plants in this medium will contain the minimum value of the mineral elements.

Besides, data of the two locations showed that adding compost at $25 \%$ or $50 \%$ gave the highest significant increases in the content of N, P, K, Cu, Mn and $\mathrm{Zn}$ in the leaves of the used plant, compared with the other media (Table 5 and 6).

These results were probably due to the presence of compost at a suitable ratio which led to decrease the $\mathrm{pH}$ value of the medium besides it contains a high value of $\mathrm{N}, \mathrm{P}, \mathrm{K}, \mathrm{Cu}, \mathrm{Mn}$ and $\mathrm{Zn}$, consequently the grown plants had absorbed a high amount of these elements, thus the content of these elements in their leaves could be increased. These results are in good agreement with those obtained by many researchers such as Habib et al. (2001), Ahmed and Ali (2005), Sherif and EL-Naggar (2005), EL-Maadawy et al. (2006), EL-Kholy et al. (2010), Barakat et al.(2012) and Mazher et al. (2012) on other plants.

Furthermore, data of the two locations indicated that adding sand at $25 \%$ or $50 \%$ to the calcareous soil or using an equal mixture of the three materials (calcareous soil + compost + sand) together, gave significant increases in the content of N, P, K, Mn and $\mathrm{Zn}$ in the leaves of Gazania plant, compared with using calcareous soil alone (Tables 5 and 6).

These results were probably due to that presence of sand and/ or compost each at specific ratio led to decrease each of soil $\mathrm{pH}$ and percentage of calcium carbonate of the calcareous soil (Table A) thus improving the availability of the nutrition elements, consequently the grown plants had absorbed high elements amounts and the content of these elements in their leaves would be increased. These results are in good agreement with those obtained by Adeleye et al. (2010) on other plants.

\section{Table 6. Means of copper, manganese and zinc content (ppm) in leaves of Gazania plant as influenced by different growing media in two locations of Alexandria.}

\begin{tabular}{|c|c|c|c|c|c|c|c|c|c|}
\hline \multirow{2}{*}{ } & \multicolumn{3}{|c|}{$\begin{array}{c}\text { Media content } \\
(\mathrm{v} / \mathrm{v})\end{array}$} & \multicolumn{2}{|c|}{$\begin{array}{c}\text { Copper } \\
(\mathrm{ppm})\end{array}$} & \multicolumn{2}{|c|}{$\begin{array}{c}\text { Manganese } \\
(\mathbf{p p m}) \\
\end{array}$} & \multicolumn{2}{|c|}{$\begin{array}{c}\text { Zinc } \\
(\mathbf{p p m})\end{array}$} \\
\hline & Calcareous & Compos1 & Sand & Maamour: & Montaza & Maamourc & Montaza & Maamoura & Montaza \\
\hline $\mathrm{T}_{1}$ & 100 & 0 & 0 & $5.87_{\mathrm{b}}$ & $5.43^{\mathrm{b}}$ & $41.20^{\mathrm{d}}$ & $33.10^{\mathrm{a}}$ & $24.90^{\mathrm{c}}$ & $40.50^{c}$ \\
\hline $\mathrm{T}_{2}$ & 75 & 25 & 0 & $7.23^{\mathrm{ab}}$ & $8.07^{\mathrm{ab}}$ & $66.60^{\mathrm{c}}$ & $81.20^{\mathrm{a}}$ & $53.60^{\mathrm{a}}$ & $72.60^{\mathrm{ab}}$ \\
\hline $\mathrm{T}_{3}$ & 50 & 50 & 0 & $9.93^{\mathrm{a}}$ & $8.80^{\mathrm{a}}$ & $120.70^{\mathrm{a}}$ & $89.00^{\mathrm{a}}$ & $51.20^{\mathrm{a}}$ & $82.60^{\mathrm{a}}$ \\
\hline $\mathrm{T}_{4}$ & 75 & 0 & 25 & $7.07^{\mathrm{ab}}$ & $6.09^{\mathrm{b}}$ & $63.20^{\mathrm{c}}$ & $45.30^{\mathrm{c}}$ & $48.80^{\mathrm{ab}}$ & $67.60^{\mathrm{b}}$ \\
\hline $\mathrm{T}_{5}$ & 50 & 0 & 50 & $6.17^{\mathrm{b}}$ & $7.00^{\mathrm{ab}}$ & $64.00^{\mathrm{c}}$ & $51.70^{\mathrm{c}}$ & $44.90^{\mathrm{b}}$ & $64.80^{\mathrm{b}}$ \\
\hline $\mathrm{T}_{6}$ & 33.33 & 33.33 & 33.33 & $7.63^{\mathrm{ab}}$ & $7.13^{\mathrm{ab}}$ & $89.20^{\mathrm{b}}$ & $62.50^{\mathrm{b}}$ & $49.90^{\mathrm{ab}}$ & $77.90^{\mathrm{ab}}$ \\
\hline L.S. & D. at 0.05 & & & 3.19 & 2.27 & 9.37 & 8.29 & 5.88 & 11.07 \\
\hline
\end{tabular}

Means at the same column followed by same letter (s) are not significantly different at 0.05 porobabilty level.

L.S.D. $=$ Least Significant Difference at 0.05 of probability. 


\section{REFERENCES}

AbdEL-Hady, W. (2006). Effect of chemical and biofertilization and compost on physical and chemical properties of sand medium affecting growth and flowering of some ornamental plants. Ph.D. Thesis, Fac. of Agric., Mansoura Univ., Egypt.

Abd EL-Kader, A.A., S.M. Shaaban and M.S. Abd EL-Fattah (2010). Effect of irrigation levels and organic compost on okra plants (Abelmoschus esculentus, L.) grown in sandy calcareous soil. Agric. BioI. J.N. Am., 1(3): 225- 231.

Abdel-Fattah, Gehan, H., B. Rezk Alia and Amal, S., ELFouly (2008).Effect of some organic additives to sand on growth and chemical composition of Brassaia actinophylla (End 1) Harms plant. Annals of Agric. Sci. Moshtohor, Vol. 46(4): 477-482.

Abo El-Fadl, I., S. El-Deeb and M. Abd-Ella (1989). Salt tolerance of Geranium in two types of soil. J. Agric. Res., 37 (1):231-245.

Abou-Bakr, M. and S. EL-Maghraby (1994). Effect of organic manure on sugar beet at various growth rates in calcareous soil. Annals of Agric. Sci., Moshtohor, 32(4):1749-1757.

Adeleye, E.O., L.S.Ayeni and S.O. Ojeniyi (2010). Effect of poultry manure on soil physic-chemical properties, leaf nutrient contents and yield of yam (Dioscorea rotundata) on Alfisol in Southwestern Nigeria. J. American Sci., 6(10): 632- 64].

Ahmed, M. and E. Ali (2005). Effect of different sources of organic fertilizers on the accumulation and movement of NPK in sandy calcareous soils and the productivity of wheat and grain sorghum. Assiut J. of Agric. Sci., 36 (3): 27-28.

Agamy, R.A., G.F. Mohamed and M.M. Rady (2012). Influence of the application of fertilizer type on growth, yield, anatomical structure and some chemical components of wheat (Triticum aestivum, L.) grown in Newly Reclaimed soli. Aust. J. Basic Appl. Sci., 6(3): 561- 570 .

Badr, M., A. Wallace and A. El-Gazzar (1979). Effect of soil conditions and botanical characters on the nutrient level of the leaves of some Egyptian flowers and ornamental plants. Alex. J. agric. Res. 27 (1): 133-159.

Ball, v. (1992). Ball Red Book, Geo. J. Bell Publishing, USA.

Barakat, M.R., T.A. Yehia and B.M. Sayed (2012). Response of Newhall Noval orange to bio-organic fertilization under Newly Reclaimed area conditions. I: Vegetative growth and nutritional status. J. Hort. Sci. and Ornamental Plants, 4( 1): 18-25.

Chapman, H.D. and P.F, Pratt (1961). Methods of analysis for soils, Plants and Water. Agric. Pub. Unv. of California, Reverside, USA.
EL-Gizy, S. and M. Rifaat (2001). Response of some tomato cultivars to saw-dust compost and nitrogen sources under a calcareous soil condition. 1- Plant growth, yield and nutrient uptake. Annals of Agric. Sci., Moshtohor, 39(2): 1089-1111.

EL-Kholy, M., S. Mahrous and S. EL-Tohamy (2010). Integrated effect of mineral, compost and biofertilizers on soil fertility and tested crops productivity. Research J.of Agric. And Biol. Sci., 6(5): 670- 682.

EL-Maddawy, E., A. EL-Malt, M. EL-Khateeb and Z. ELSadak(2006). Physiological studies on Hippeastrum vittatum L. plants. 1- Effect of growing media on growth, flowering, bulblets formation and chemical composition. Egypt. J. of Appl. Sci., 21 (6B): 710-723.

EI-Mahdy, W. (2001). Effect of different growing media and fertilizer treatments on the growth of Canna indica, L. plants. M.Sc. Thesis, Fac. Agri. Alex. Univ.

EI-Menaie, H., A. AI-Shatti and N. Suresh (2008). Effect of growing media on growth and flowering patterns of Gardenia jasminoides under arid conditions. European Journal of scientific Research ISSN 1450-2J6x Vol. 24 No.1, 69-73.

EL-Naggar, A., A. EL-Naggar and F. EL-Fawakhry (2004). Physiological studies on growth and flowering of Cyperus papyrus, L. 1- Effect of growing media and water requirements. Alex. J. Agric. Res. 49(3): 93- 105.

El-Sayed, S. (1991). Salt tolerance evaluation for some flowers and ornamental plants. M.Sc. Thesis, fac. of Agric., Alex. Univ. Egypt.

EL-Sayed, Boshra, A. and S. EL-Shal (2008). Effect of growing media and humic acid on schefflera quality (Brassaia actinophylla).J. Agric. Sci., Mansoura Univ., 33(1): 371-381.

Evenhuis, B. and P.W. Dewaard (1980). Principles and Practices in Plant Analysis. FAO Soil Bull., 38: 152-163.

Fadl, A.M.N. (2013). Effect of growing media and mineral fertilization on growth of Lawns. MSc. Thesis, Fac. of Agric., Alex. Univ., Egypt.

Habib, F., Negm and M. Hassan (2001). Composting of sugar beet residues. (3) The effect of application dose to a calcareous soil on plant growth and nutrient uptake. Egypt. J. of Agric. Res., 79(4):1263-1274.

Manoly, N. (1996). Effect of soil type, fertilization, bulb size and growth regulators on growth, flowering and chemical composition of iris plants. Ph.D. Thesis, Fac.Agric., Minia Univ.

Mazher, Azza, A.M., Mona H. Mahgoup, Kh. M. Abd ELRheem and Sahar M.Zaghloul (2012). Influence of Nile Compost application on growth, flowering and chemical composition of Amaranthus tricolor under different irrigation intervals. Middle-East J. Sci. Res.;12(6): 751759. 
Sayed, R. (1993). Effect of some growing media and microelement treatment on growth, flowering and oil content of Achillea millefolium, L. plants. M.Sc. Thesis Fac.Agric., Minra Univ., Egypt.

Sherif, Fatma, K. and A. EL-Naggar (2005). Effect of biofertilizer application to manure on Calla lily (Zantedeschia aethiopica, L. Spring) production and nutrients release in sandy soil. Alex. J. Agric. Res., 50(1): 181- 192.

Singh, P.V. (1999). Effect of organic and inorganic sources of nutrients on rainfall wheat. Indian J. Agron., 44(2): $347-$ 352.

Snedecor, G. and W. Cochran (1974). Statistical Methods. Sixth Edition. Iowa State Unrversity Press. Ames. Iowa, USA.
Wang, X., Q. Zbou, T. Chen, G. Yinghua and T. Peidong (2003). Effects of land utilization of sewage sludge on grass and soils. Chinese Journal of Enviromental Science. 2003-02.

Yadava, U.L. (1986). A raped and non-destructive method to determined chlorophyll in intact leaves. Hort. Sci., 21 (6): 1449-1450.

Yang, Y., J. Wei and Q. Li. (2010). Effects of urban sludge composition on growth of Lawn grass. Journal of Anhui Agricultural Sciences.Vol. 38(11); P. 5586-5587.

Zhao, L., Y. Li and T. Chen (2002). The municipal sewage sludge compost used as Lawn medium. (J). Acta Ecological Sinica; 22(6): 797-801.

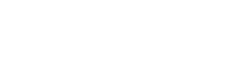

\section{تأثير بهض بيئلت النموعل نمو وإزهار نبلت الجازلنيا}

بدرية لأحمد هسن، محمود خطلب هسين، طارق محمود القيعى، بشينة محمد وحيلة

\% \% للتربة الجيرية إلى زيادات معنوية فى جمبع الصفلت المدروسة قُريبا بالمقارنة بلستخدلم التربة الجيرية مفردة. بالأضافة إلى ذلك لُٔهرت نتائج موقعى الدرلسة أن

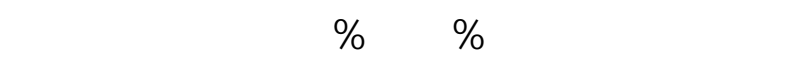
من التربة الجيرية والكومبوست والرهل لم تؤثر معنويا على مغلم الصفلت المدروسة لنبت الجازانيا (نمو خضرى الجير وزهرى وجذرى وتحليل كيماوى) بالمقارنة بإلستخدلم التربة الجيرية مفردة بلستثناء بعض القراءات مل قطدريل فليماري النورة وطول حلملها ووزنها الجف وأيضا محتوى الأورق من كل من النيتروجين والفوسفور والبوتلسيوم والمنجنيز

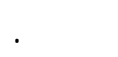

عموما يمكن التوصية بإضفافة الكومبوست بنسبة عro

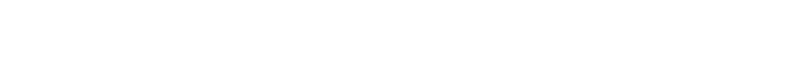

لجرى هذا البهث فـ معهد بحوث البساتين بمركز

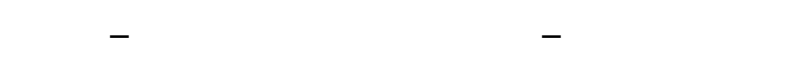
خلل عل rا بr في موقعين مختلفين هما المعمورة والمنتزة بهرف لستخدلم(7) بيئت زراعية مختلفة والناتجة

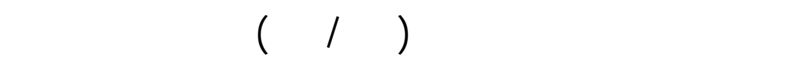
والرهل للتربة الجيرية على النمو الخضرى والزهرى

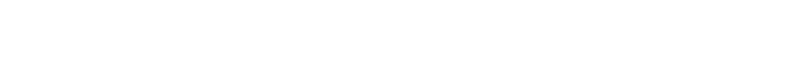

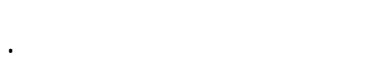
هذا وقد أظلهرت النتائج المتحصل عليها من موقعى الدرلسة أن لستخده التربة الجيرية مفردة أعطى ألق قيم لمظم صفلت النمو (خضرى- زهرى- جذرى) والتحاليل الكيماوية المدروسة لنبلت الجازانيا بالمقارنة بالبيئلت

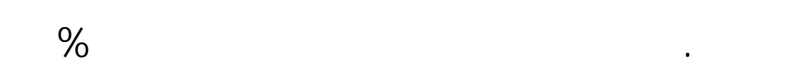
الجازانيا بجووة عالية. 